\title{
Malaria in travellers returning or migrating to Canada: surveillance report from CanTravNet surveillance data, 2004-2014
}

\author{
Andrea K. Boggild MSc MD, Jennifer Geduld MSc, Michael Libman MDCM, Cedric P. Yansouni MD, \\ Anne E. McCarthy MD, Jan Hajek MD, Wayne Ghesquiere MD, Jean Vincelette MD, Susan Kuhn MD, \\ David O. Freedman MD, Kevin C. Kain MD
}

\section{Abstract}

Background: Malaria remains the most common specific cause of fever in returned travellers and can be life-threatening. We examined demographic and travel correlates of malaria among Canadian travellers and immigrants to identify groups for targeted pretravel intervention.

Methods: Descriptive data on ill returned Canadian travellers and immigrants presenting to a CanTravNet site between 2004 and 2014 with a diagnosis of malaria were analyzed. Data were collected using the GeoSentinel data platform. This network comprises 63 specialized travel and tropical medicine clinics, including 7 Canadian sites (Vancouver, Calgary, Toronto, Ottawa, Winnipeg and Montréal), that contribute anonymous, delinked, clinician- and questionnaire-based travel surveillance data on all ill travellers examined to a centralized Structure Query Language database.

Results: During the study period, 20345 travellers and immigrants were evaluated, and 93\% had a travel-related diagnosis. Of these, 437 (2.1\%) patients received 456 malaria diagnoses, the most common species being Plasmodium falciparum $(n=282$, $61.8 \%)$. People travelling to visit friends and relatives were most well-represented $(n=169,38.7 \%)$, followed by business travellers ( $n=71,16.2 \%)$. Sub-Saharan Africa was the most common source region, accounting for $341(74.8 \%)$ malaria diagnoses, followed by South Central Asia ( $n=55,12 \%)$. Nigeria was the most well-represented source country, accounting for 41 cases $(9.0 \%)$. India, a high-volume destination for Canadians, accounted for 40 cases (8.8\%), 36 of which were caused by Plasmodium vivax. Of 456 malaria diagnoses, 26 (5.7\%) were severe. Of 377 nonimmigrant travellers with malaria, $19.9 \%(n=75)$ travelled for less than 2 weeks, and $7.2 \%(n=27)$ travelled for less than 1 week.

Interpretation: This analysis provides an epidemiologic framework for Canadian practitioners encountering prospective and returned travellers. It confirms the importance of preventive measures and surveillance associated with travel to sub-Saharan Africa and India, particularly by travellers visiting friends or relatives. Short-duration travel confers important malaria risk.

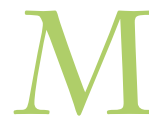
alaria remains the most common specific cause of fever in returned travellers ${ }^{1}$ and can cause severe life-threatening illness, end-organ damage and cerebral complications. ${ }^{2}$ Every year, North Americans die of imported malaria, mostly because of delays in diagnosis and treatment. ${ }^{2-4}$ However, malaria is preventable by adherence to strategies such as chemoprophylaxis and personal protective measures, including the use of insecticide-treated bed nets and clothing, as well as insect repellents. ${ }^{5,6}$ Although bed nets and repellents are commercially available across Canada, chemoprophylactic medications require a prescription and thus necessitate an encounter with a health care professional before travel to be obtained. Knowledge gaps exist in our understanding of migration medicine practice and the impact of imported pathogens by Canadian travellers and new immigrants, of which malaria is one of the most important. Barri- ers to the uptake of malaria preventive strategies, including chemoprophylaxis and personal protective measures, in the mobile Canadian population are poorly understood, but the first step to reducing these barriers is defining the scope and epidemiology of imported malaria to Canada.

We aim to better inform pretravel malaria risk assessment and posttravel management, and to illuminate changing patterns of imported malaria by presenting a Canada-specific

Competing interests: None declared.

This article has been peer reviewed.

Correspondence to: Andrea Boggild, andrea.boggild@utoronto.ca CMAJ Open 2016. DOI:10.9778/cmajo.20150115 
surveillance summary of malaria in a cohort of returned travellers and new immigrants presenting for care at CanTravNet sites over a 10 -year period.

\section{Methods}

\section{Setting}

Seven Canadian sites from 5 provinces (British Columbia, Alberta, Manitoba, Ontario and Quebec), also belonging to the GeoSentinel Global Surveillance Network, constitute CanTravNet, as described. ${ }^{7}$ These sites are large referral-based outpatient centres staffed by specialists in travel and tropical medicine, which serve the Greater Vancouver-Victoria, Calgary, Winnipeg, Toronto, Ottawa and Montréal metropolitan areas and could account for service of almost $50 \%$ of the Canadian population. Network sites have been accrued over time, with inaugural sites in Toronto (1997) and Ottawa (1997), and more recent additional sites in Victoria-Vancouver (2009), Montréal (2007 and 2011), Calgary (2012) and Winnipeg (2016).

\section{Sources of data}

Data were collected using the GeoSentinel Surveillance Network data platform. This network comprises 63 specialized travel and tropical medicine clinics on 6 continents, which contribute denominalized clinician- and questionnaire-based travel surveillance data on all ill travellers who undergo examination to a centralized Structured Query Language database ${ }^{8}$ (for additional details see www.geosentinel.org). Collected data include patient demographics, details of recent travel, 5-year travel history, purpose of travel and pretravel encounter history. Final diagnoses are made by attending physicians at the CanTravNet site and assigned a diagnostic code selected from a standardized list of more than 500 diagnostic entities, including etiologic (e.g., Plasmodium falciparum) and syndromic (e.g., fever) diagnoses. All CanTravNet sites contribute microbiologically confirmed data, where available, based on the best national reference diagnostic tests (including molecular diagnostics) available at the time. Further details regarding CanTravNet can be found at www.istm.org/cantravnet, and additional details regarding the CanTravNet data source and definitions are as described.

\section{Definitions and classifications}

\section{Reason for most recent travel}

Six travel purpose designations were used, including immigration (including refugee), tourism, business, missionary/volunteer research/aid work, visiting friends and relatives and "Other," which includes students, military personnel and medical tourists. Travel for the purpose of visiting friends and relatives is defined as travel by an immigrant who is ethnically or racially distinct from the majority population in their current country of residence who returns to his or her homeland to visit friends and relatives. Such travel also includes children of foreign-born parents (i.e., second-generation immigrants) who return to their parent's homeland to visit friends and relatives. The term is typically applied to people travelling from a high-income country of current residence to a low-income country of origin. ${ }^{9}$
Countries of exposure and travel were assigned to 1 of 8 hard-coded regional classifications (within the GeoSentinel database) where malaria is transmitted: Central America, the Caribbean, South America, North Africa, sub-Saharan Africa, South Central Asia, Southeast Asia and Oceania.

\section{Inclusion criteria}

Demographic, clinical and travel-related data on Canadian citizens and new immigrants to Canada encountered after completion of their international travel or residence abroad and seen in any of 6 CanTravNet sites from September 2004 to September 2014 were extracted and analyzed. Only patients with a probable or confirmed final diagnosis of malaria (specific cause as described previously ${ }^{7}$ ) were included. A "returned traveller" refers to a single travel episode within the database, where patients could appear more than once if they had more than 1 episode of malaria related to different trips, or if their illness was diagnosed with more than 1 species of malarial infection.

\section{Statistical analysis}

Extracted data were managed in a Microsoft Access database and analyzed descriptively. Travellers were described by purpose of travel, demographics and travel metrics (including pretravel encounters, diagnoses, country of exposure and region of travel). Differences between groups of travellers were compared using a Fisher exact test or $\chi^{2}$ analysis. All statistical computations were performed on SigmaStat 2.03 software (SPSS Inc., Chicago, Ill.) or GraphPad Prism software (GraphPad Software Inc., La Jolla, Calif.).

\section{Results}

During the study period, 20345 travellers and immigrants presented to a CanTravNet site, $93 \%$ of whom had a travelrelated diagnosis. Of these, 437 (2.1\%) patients received 456 diagnoses of malaria, which accounts for $10.9 \%$ of the total number of malaria cases $(n=4190)$ reported in Canada through the national notifiable disease surveillance system over a similar 10 -year period; $63.7 \%$ of patients with a malaria diagnosis were male. ${ }^{10}$ The most common malaria species imported by returned travellers and new immigrants in this analysis was $P$. falciparum $(n=282,61.8 \%)$. Four cases of $P$. falciparum-Plasmodium vivax coinfection, and 2 cases of $P$. falciparum-Plasmodium ovale coinfection were documented. People travelling for the purpose of visiting friends and relatives were the most well-represented $(n=169,38.7 \%)$, followed by business travellers $(n=71,16.2 \%)$, missionaries, volunteers or aid workers $(n=69,15.8 \%)$, immigrants $(n=60,13.7 \%)$, tourists $(n=52,11.9 \%)$ and students or military personnel $(n=16$, $3.7 \%)$. Demographic characteristics of the malaria patients presenting to CanTravNet sites are summarized in Table 1.

Sub-Saharan Africa was the most common region of acquisition for malaria, accounting for $326(n=71.5 \%)$ cases, followed by South Central Asia ( $n=55,12.6 \%)$, South America $(n=10,2.2 \%)$ and North Africa (Sudan and South Sudan) $(n=$ $10,2 \%)$ (Table 1). Nigeria was the most well-represented source country, accounting for 41 cases $(9.4 \%)$. India, a partic- 


\section{OPEN}

Research

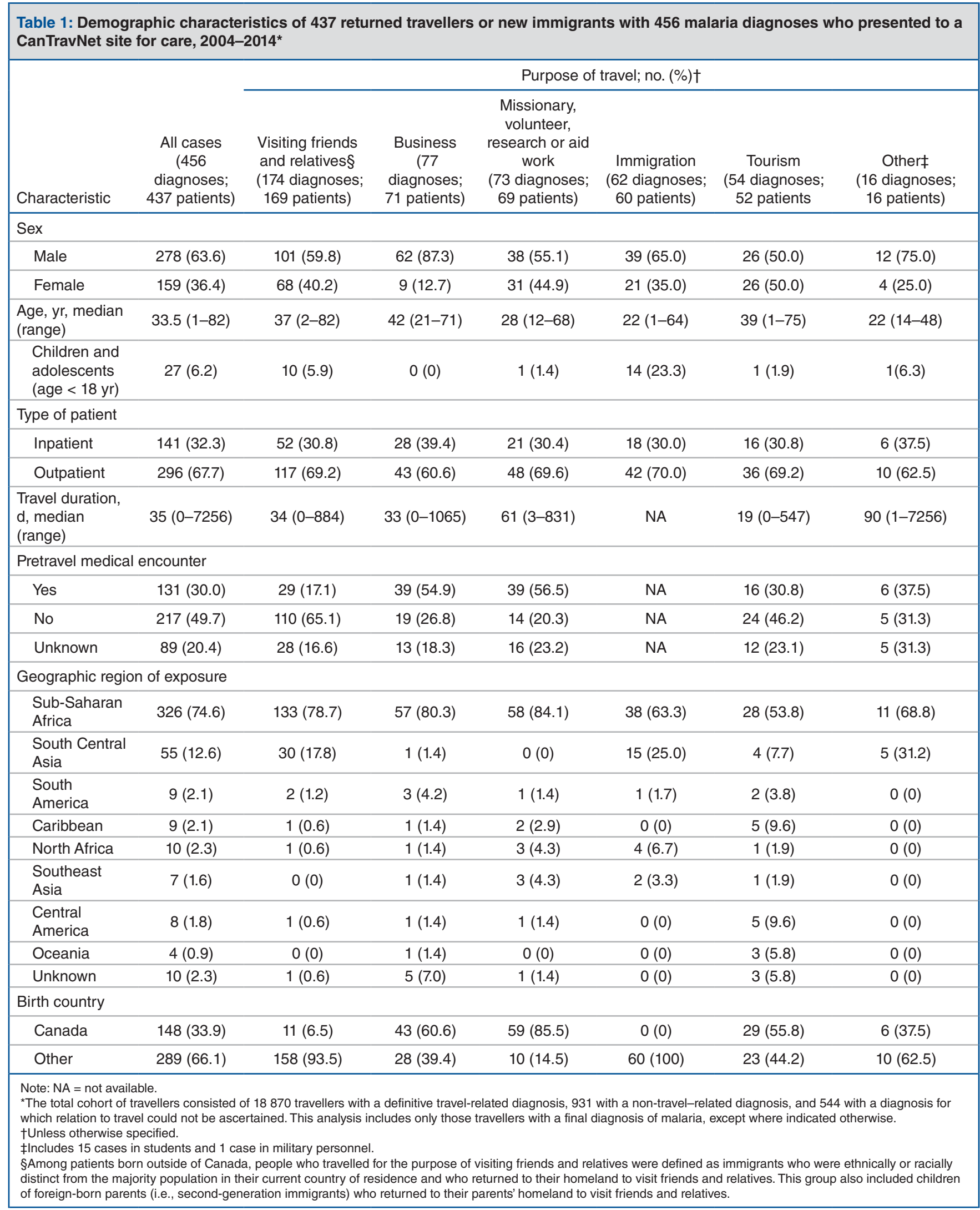


ularly high-volume destination for Canadians, accounted for 40 cases $(9.2 \%), 36$ of which were caused by $P$. vivax. In total, $60.7 \%$ of $P$. vivax cases were imported from the Indian subcontinent (51/84). Five cases of $P$. falciparum were imported from Haiti and 3 from Dominican Republic. Source regions by purpose of travel are listed in Table 1, and source countries by type of malaria are listed in Table 2. Table 3 lists source countries by year of import to Canada.

Of 456 diagnoses among returned travellers or new immigrants with malaria who presented for care at a CanTravNet site, fever was the presenting symptom in $83.1 \%(n=379)$, although this presentation varied by causative species (Table 2 ). Malaria was also the more common specific cause of fever in this analysis, occurring in $15 \%$ of returned travellers or new immigrants presenting with fever. Other common presenting symptoms in those with malaria diagnoses included fatigue $(n=$ $153,33.6 \%)$, abnormal laboratory tests $(n=146,32 \%)$ and gastrointestinal problems $(n=114,25 \%)$. Of the total 456 malaria diagnoses, $26(5.7 \%)$ were classified as severe, but varied by travel reason, with $9.6 \%(7 / 73)$ of cases in missionaries classi-

\begin{tabular}{|c|c|c|c|}
\hline Diagnosis & $\begin{array}{c}\text { Total no. of malaria } \\
\text { diagnoses in database }\end{array}$ & $\begin{array}{l}\text { No. }(\%) \text { of malaria } \\
\text { diagnoses }{ }^{*} \text { in travellers } \\
\text { presenting with fever }\end{array}$ & Three most common source countries \\
\hline Malaria & 456 & $379(83.1)$ & \\
\hline Plasmodium falciparum & 282 & $237(84.0)$ & Nigeria, Ghana, Ivory Coast (includes severe malaria) \\
\hline Severe (complicated) & 26 & $23(88.5)$ & \\
\hline Plasmodium vivax & 85 & $77(90.6)$ & India, Pakistan, Guyana \\
\hline Species unknown & 39 & $22(56.4)$ & Burkina Faso, Sierra Leone \\
\hline Plasmodium ovale & 21 & $18(85.7)$ & Nigeria, Ghana, Cameroon \\
\hline Plasmodium malariae & 3 & $2(66.7)$ & Nigeria, Ghana, Cameroon \\
\hline
\end{tabular}

Table 3: Most common source countries by year of import for 456 cases of malaria among ill returned travellers and new immigrants evaluated at CanTravNet sites, 2004-2014

\begin{tabular}{|c|c|c|c|c|c|c|}
\hline \multirow{2}{*}{$\begin{array}{l}\text { Year of } \\
\text { import }\end{array}$} & \multirow{2}{*}{$\begin{array}{l}\text { No. of diagnoses } \\
\text { of malaria (no. } \\
\text { travellers with } \\
\text { malaria) }\end{array}$} & \multirow{2}{*}{$\begin{array}{l}\text { Total no. of } \\
\text { cases of } \\
\text { malaria reported } \\
\text { to the Public } \\
\text { Health Agency } \\
\text { of Canada }{ }^{10}\end{array}$} & \multirow{2}{*}{$\begin{array}{l}\text { Cases reported } \\
\text { to the Public } \\
\text { Health Agency } \\
\text { of Canada seen } \\
\text { at CanTravNet } \\
\text { sites, \% }\end{array}$} & \multicolumn{3}{|c|}{ Most common source countries (no. of cases) ${ }^{\star}$} \\
\hline & & & & First & Second & Third $†$ \\
\hline $2004 \ddagger$ & $4(4)$ & 375 & $4.3 \S$ & Afghanistan (1) & Guatemala (1) & Venezuela (1) \\
\hline 2005 & $10(9)$ & 365 & 2.7 & Ghana (2) & Guinea (2) & - \\
\hline 2006 & $21(20)$ & 333 & 6.3 & Nigeria (6) & Ivory Coast (4) & Mozambique (4) \\
\hline 2007 & $31(28)$ & 384 & 8.1 & India (5) & Ivory Coast (3) & Cameroon (2), Nigeria (2) \\
\hline 2008 & $45(42)$ & 372 & 12.1 & Kenya (5) & Nigeria (5) & - \\
\hline 2009 & $36(35)$ & 364 & 9.9 & India (5) & Ghana (4) & - \\
\hline 2010 & $41(40)$ & 514 & 8.0 & Cameroon (3) & Ghana (3) & Honduras (3), Nigeria (3) \\
\hline 2011 & $60(58)$ & 517 & 11.6 & India (10) & Ghana (7) & Nigeria (6) \\
\hline 2012 & $64(62)$ & 477 & 13.4 & India (7) & Pakistan (6) & Sierra Leone (5) \\
\hline 2013 & $95(90)$ & 489 & 19.4 & Cameroon (12) & Guinea (7) & Nigeria (7) \\
\hline 2014ף & $49(48)$ & Unavailable & Unavailable & Benin (4) & Ghana (4) & - \\
\hline Total & $456(437)$ & 4190 & 11.3 & Nigeria (41) & India (40) & Ghana (32) \\
\hline
\end{tabular}




\section{OPEN}

fied as severe, $9.1 \%(7 / 77)$ in business travellers, $7.4 \%(4 / 54)$ in tourists, $3.2 \%(2 / 62)$ in immigrants and $2.9 \%(5 / 174)$ in travellers visiting friends and relatives (Table 4). Collectively, severe malaria was overrepresented among travellers not visiting friends and family and nonimmigrant travellers (19/221 diagnoses) compared with the immigrants or travellers who were visiting friends and relatives $(7 / 236$ diagnoses $)(p=0.014)$. About one-third of travellers and new immigrants with malaria $(n=$ 154) required inpatient management of their illness, $81.2 \%$ of which cases were caused by $P$. falciparum $(n=125)$ (Table 1$)$.

About 30\% $(n=131)$ of travellers with malaria had received pretravel care (Table 1). The most well-represented group of travellers with malaria, travellers visiting friends and relatives, had the lowest rate of pretravel encounters (Table 1). The next most well-represented groups of travellers, those travelling for business and missionary, volunteer, research or aid work, had the highest uptake of pretravel encounters $(54.9 \%$ and $56.5 \%$, respectively). Of travellers with malaria who had received pretravel care $(n=131)$, only $68(51.9 \%)$ reported taking some sort of chemoprophylaxis (Table 4). Although it is unknown how many travellers with malaria were adherent to prophylaxis, at least $5(1.1 \%)$ were specifically noted as having either missed doses of doxycycline throughout travel or run out of pills before departure from the malaria-endemic area (Table 4).

Of 377 returned nonimmigrant travellers with malaria presenting for care at a CanTravNet site, $19.9 \%(n=75)$ had a trip duration of less than 2 weeks, and $7.2 \%(n=27)$ had travelled for less than 1 week. Of malaria diagnoses among nonimmigrant travellers with short-duration travel ( $<2$ weeks), $68.0 \%$ were caused by $P$. falciparum (51/75), and $9.3 \%$ were severe (7/75). Pretravel advice had been obtained by $34.7 \%$ (26/75) of travellers with malaria who had travelled for less than 2 weeks, which was similar to those with any duration of travel (Table 1).

\section{Interpretation}

Our analysis of surveillance data on ill returned Canadians provides an epidemiologic framework for Canadian practitioners encountering prospective travellers. About two-thirds of malaria cases in this analysis occurred in men, a phenomenon noted previously. ${ }^{11,12}$ Higher rates of malaria and deaths due to malaria among male travellers may reflect both biological

Table 4: Cases of malaria by travel reason among 18870 ill returned travellers presenting to a CanTravNet site, 2004-2014

\begin{tabular}{|c|c|c|c|c|c|c|c|c|c|}
\hline \multirow[b]{2}{*}{$\begin{array}{l}\text { Reason for } \\
\text { travel }\end{array}$} & \multirow{2}{*}{$\begin{array}{l}\text { Total no. of } \\
\text { malaria } \\
\text { diagnoses } \\
\text { (no. of } \\
\text { travellers) }\end{array}$} & \multicolumn{6}{|c|}{ Type of malaria; no. of diagnoses } & \multirow{2}{*}{$\begin{array}{c}\text { Top } 3 \\
\text { countries of } \\
\text { exposure }\end{array}$} & \multirow[b]{2}{*}{$\begin{array}{r}\text { Received } \\
\text { prophylaxis }\end{array}$} \\
\hline & & $\begin{array}{l}\text { Plasmodium } \\
\text { falciparum }\end{array}$ & $\begin{array}{l}\text { Severe } \\
\text { malaria }\end{array}$ & $\begin{array}{c}\text { Plasmodium } \\
\text { vivax }\end{array}$ & $\begin{array}{c}\text { Plasmodium } \\
\text { ovale }\end{array}$ & $\begin{array}{l}\text { Species } \\
\text { unknown }\end{array}$ & $\begin{array}{l}\text { Plasmodium } \\
\text { malariae }\end{array}$ & & \\
\hline $\begin{array}{l}\text { All } \\
(n=18870)\end{array}$ & $456(437)$ & 282 & 26 & 85 & 21 & 39 & 3 & See Table 2 & $68^{*}$ \\
\hline $\begin{array}{l}\text { Immigration } \\
(n=4967)\end{array}$ & $62(60)$ & 35 & 2 & 15 & 4 & 5 & 1 & $\begin{array}{l}\text { India, } \\
\text { Nigeria, } \\
\text { Liberia }\end{array}$ & NA \\
\hline $\begin{array}{l}\text { Visiting } \\
\text { friends and } \\
\text { relatives } \\
(n=1966)\end{array}$ & $174(169)$ & 117 & 5 & 38 & 7 & 7 & 0 & $\begin{array}{l}\text { Nigeria, } \\
\text { India, } \\
\text { Cameroon }\end{array}$ & 28 \\
\hline $\begin{array}{l}\text { Business } \\
(n=1643)\end{array}$ & $77(71)$ & 51 & 7 & 7 & 3 & 8 & 1 & $\begin{array}{l}\text { Burkina } \\
\text { Faso, } \\
\text { Ghana, } \\
\text { Guinea }\end{array}$ & 7 \\
\hline $\begin{array}{l}\text { Other† } \\
(n=498)\end{array}$ & $16(16)$ & 8 & 1 & 4 & 0 & 3 & 0 & $\begin{array}{l}\text { India, } \\
\text { Benin, } \\
\text { Burkina } \\
\text { Faso, } \\
\text { Tanzania }\end{array}$ & 2 \\
\hline
\end{tabular}


(e.g., attractiveness to vectors) and behavioural (e.g., adherence to chemoprophylaxis) risk factors, ${ }^{11,13-17}$ although their continued overrepresentation in epidemiologic analyses speaks to the need for better, targeted prevention initiatives.

Business travellers were overrepresented among returned travellers with malaria presenting for care at a CanTravNet site. As a group, these travellers tended to be born in Canada and conducting business in West Africa, the region with the highest overall relative risk of malaria. ${ }^{18}$ Most cases of malaria in business travellers in this analysis were caused by potentially fatal $P$. falciparum. Although more than half of business travellers with malaria had received pretravel advice, few reported taking chemoprophylaxis. Thus, there is a clear disconnect between known travel to a risk area and adherence to chemoprophylaxis in this group. Understanding barriers to uptake of malaria preventive measures, which includes chemoprophylaxis ${ }^{5}$ and insect precautions ${ }^{6}$ after the pretravel encounter among business travellers should be strategically prioritized to reduce morbidity and potential mortality.

Travellers visiting friends and relatives constitute a particular group at high-risk for malaria, ${ }^{1,8,9,19,20}$ and were the most well-represented group of travellers with malaria in our analysis. Unlike business travellers, these travellers had the lowest rates of pretravel encounter of any type of traveller, a finding that has been noted in previous studies. ${ }^{9}$ Because malaria is preventable with appropriate chemoprophylaxis and insect precautions, poor uptake of pretravel advice and intervention may translate into a proportionately higher burden of malaria among travellers visiting friends and relatives. Understanding the barriers to obtaining a pretravel consultation in this population is necessary to inform strategic initiatives aimed at reducing the burden of imported malaria in this group of highly mobile Canadians and their children.

Our data confirm the overwhelming importance of travel to sub-Saharan Africa and the Indian sub-continent, particularly by travellers visiting friends and relatives, but also other travellers, to the importation of malaria to Canada. The top represented source countries in this analysis were Nigeria and India, although countries such as Ghana, Ivory Coast, Cameroon and Burkina Faso were also well-represented, and mostly accounted for imports of $P$. falciparum. Although most cases of malaria in this analysis were imported from sub-Saharan Africa, only about half of tourist travellers acquired their malaria in this region. Compared with other types of traveller, tourists appeared to acquire malaria in regions such as Central America, the Caribbean and Oceania, which may reflect the perception of low malaria risk in these areas and consequent poor adherence to prophylaxis and personal protective measures. Continued reinforcement of personal protective vigilance, including insect precautions, in the pretravel setting, even for possibly low-risk itineraries, is important.

India was the second most common source country in our analysis and contributed mostly to the burden of imported $P$. vivax infection, which raises the issue of how to best address malaria prevention in Canadian travellers to the Indian subcontinent. Although clearly a risk in many parts of the Indian subcontinent, the true epidemiology of malaria in India is complex owing to seasonal variability, widespread urban and rural transmission and the difficulty in separating multiple relapses of $P$. vivax from new infections. These factors contribute to confusion and inconsistent recommendations around malaria prevention strategies for travellers to India. An individualized approach to malaria prevention is needed for travellers, taking into account multiple relevant factors including the season, duration, regions visited and type of travel.

Risk of malaria to Canadian travellers is a complex combination of local transmission intensity, type and duration of travel, total numbers of Canadian travellers to the malariaendemic regions and other factors. For example, India has far lower transmission intensity than most countries in subSaharan Africa, yet it was the second most common source country in this analysis. Thus, local transmission intensity, while important when advising travellers, does not directly translate into overall risk for importing malaria into Canada.

Short duration travel to malaria risk areas was confirmed to require malaria prevention, which may include chemoprophylaxis and personal protective measures, such as insecticidetreated bed nets and clothing, and the use of insect repellents. ${ }^{6}$ About one-fifth of malaria cases in this analysis were acquired on trips lasting less than 2 weeks, most of which were caused by $P$. falciparum and some of which were severe. Even trips lasting less than 1 week carried risk. Again, poor uptake of pretravel consultation, the perception of lower risk with shorter itineraries and poor translation of pretravel counselling into preventive action on the part of the traveller may have contributed to the malaria burden among short-term travellers.

Serial short-term travellers (e.g., frequent business traveller) present a challenge to the current standard of pretravel care. Many of these travellers anecdotally report that they are loathe to be on antimalarial agents continuously or near continuously, and are either nonadherent to posttravel 1- or 4-week dosing of chemoprophylaxis, or do not take chemoprophylaxis at all. Business travellers had the highest rates of hospital admission for their malaria among all groups of travellers and new immigrants presenting for care at a CanTravNet site. Similarly, missionaries, volunteers, researchers and aid workers, most of whom were Canadian-born, had high rates of severe malaria. Conversely, very few cases in immigrants or travellers visiting friends or relatives were severe, supporting the hypothesis that at least some long-term semi-immunity to malaria in people born and raised in an endemic area persists and translates into less severe clinical manifestations of disease. ${ }^{21}$ Additional clinical context of this report's findings can be found in Appendix 1, available at www.cmajopen.ca/content/4/3/E352/supp1/DC1.

\section{Limitations}

Analysis of CanTravNet data has several limitations, which have been described previously. ${ }^{7}$ This analysis pertains only to the sample of ill returned travellers and new immigrants who presented to a CanTravNet centre, thus, our conclusions may lack generalizability. Our network captured $11 \%$ of all malaria cases imported to Canada over a 10 -year period, with $19 \%$ captured during the final year of this analysis, and we noted similar rates of severe and complicated malaria to those noted 
previously. ${ }^{4,10}$ Our ability to comment on changing rates of imported malaria over time is hindered by our accrual of additional sites in the network. Our data cannot estimate incidence rates or destination-specific numerical risks for malaria. ${ }^{8,22}$ Because the Calgary site was new to CanTravNet in 2012, travellers and new immigrants to Alberta are underrepresented, which may have introduced bias given the interprovincial variation in travel patterns and preferences. In addition, owing to the nonnominal and delinked nature of the database, we cannot exclude the possibility of bias due to case-clustering within family units, for example. Data on pretravel medical consultation was missing for $20 \%$ of ill returned travellers. Finally, our network does not capture substantial numbers of pediatric malaria cases; for this reason, our data may not be generalizable to the pediatric population in Canada.

\section{Conclusion}

The data collected by the CanTravNet Surveillance Network can be used to better inform pretravel malaria risk assessment, and posttravel management, and to illuminate changing patterns of imported malaria. Malaria remains the top specific cause of fever in returned travellers, and although still mostly acquired in sub-Saharan Africa, India was the second most common source country of imported malaria over the 10 -year period studied. The lack of pretravel counselling continues to be noted in groups of high-risk travellers, such as those travelling to visit friends and relatives. Barriers to the uptake of effective chemoprophylaxis by particular risk groups and the use of insect repellent, bed nets, and other preventative measures should be systematically assessed through future research.

\section{References}

1. Wilson ME, Weld LH, Boggild A, et al. Fever in returned travelers: results from the GeoSentinel Surveillance Network. Clin Infect Dis 2007;44:1560-8.

2. Kain KC, MacPherson DW, Kelton T, et al. Malaria deaths in visitors to Canada and in Canadian travellers: a case series. CMA7 2001;164:654-9.

3. Cullen KA, Arguin PM. Malaria surveillance — United States, 2012. MMWR Surveill Summ 2014;63:1-22.

4. McCarthy AE, Morgan C, Prematunge C, et al. Severe malaria in Canada, 2001-2013. Malar 7 2015;14:151.

5. Boggild A, Brophy J, Charlebois P, et al.; Committee to Advise on Tropical Medicine and Travel (CATMAT). Canadian recommendations for the prevention and treatment of malaria: An advisory committee statement of the Committee to Advise on Tropical Medicine and Travel (CATMAT). Ottawa: Public Health Agency of Canada; 2014. Available: http://publications.gc.ca/ collections/collection_2014/aspc-phac/HP40-102-2014-eng.pdf (accessed 2015 Sept. 29).

6. Statement on personal protective measures to prevent arthropod bites. Can Commun Dis Rep 2012;38 (ACS-3 ):1-18. Available: www.phac-aspc.gc.ca/ publicat/ccdr-rmtc/12vol38/acs-dcc-3/index-eng.php (accessed 2015 Mar. 5).

7. Boggild AK, Geduld J, Libman M, et al. Travel acquired infections and illnesses in Canadians: Surveillance report from CanTravNet surveillance data, 2009 - 2011. Open Med 2014;8:e20-32.

8. Freedman DO, Weld LH, Kozarsky PE, et al. Spectrum of disease and relation to place of exposure among ill returned travelers. N Engl 7 Med 2006;354:119-30.

9. Leder K, Tong S, Weld L, et al. Illness in travelers visiting friends and relatives: a review of the GeoSentinel Surveillance Network. Clin Infect Dis 2006; $43: 1185-93$.

10. Notifiable diseases on-line: Malaria, 2004-2013. Ottawa: Public Health Agency of Canada. Available: http://dsol-smed.phac-aspc.gc.ca/dsol-smed/ndis/index-eng. php (accessed 2015 Sept. 29).

11. Schlagenhauf P, Chen LH, Wilson ME, et al.; GeoSentinel Surveillance Network. Sex and gender differences in travel-associated disease. Clin Infect Dis 2010;50:826-32.
12. Jensenius M, Han PV, Schlagenhauf P, et al.; GeoSentinel Surveillance Network. Acute and potentially life-threatening tropical diseases in western travelers-a GeoSentinel multicenter study, 1996-2011. Am 7 Trop Med Hyg 2013;88:397-404.

13. Stienlauf S, Segal G, Sidi Y, et al. Epidemiology of travel-related hospitalization. 7 Travel Med 2005;12:136-41.

14. Lüthi B, Schlagenhauf P. Risk factors associated with malaria deaths in travellers: a literature review. Travel Med Infect Dis 2015;13:48-60.

15. Legros F, Bouchaud O, Ancelle T, et al. Risk factors for imported fatal Plasmodium falciparum malaria, France, 1996-2003. Emerg Infect Dis 2007;13:883-8.

16. Christen D, Steffen R, Schlagenhauf P. Deaths caused by malaria in Switzerland, 1988-2002. Am F Trop Med Hyg 2006;75:1188-94.

17. Nicastri E, Paglia MG, Severini C, et al. Plasmodium falciparum multiple infections, disease severity and host characteristics in malaria affected travellers returning from Africa. Travel Med Infect Dis 2008;6:205-9.

18. Freedman DO. Malaria prevention in short-term travelers. $N$ Engl 7 Med 2008;359:603-12.

19. Leder K, Torresi J, Libman M, et al. GeoSentinel surveillance of illness in returned travelers, 2007-2011. Ann Intern Med 2013;158:456-68.

20. Bui YG, Trépanier S, Milord F, et al. Cases of malaria, hepatitis A, and typhoid fever among VFRs, Quebec (Canada). 7 Travel Med 2011;18:373-8.

21. Pistone T, Diallo A, Mechain M, et al. Epidemiology of imported malaria give support to the hypothesis of 'long-term' semi-immunity to malaria in subSaharan African migrants living in France. Travel Med Infect Dis 2014;12:48-53.

22. Leder K, Steffen R, Cramer JP, et al. Risk assessment in travel medicine: how to obtain, use, and interpret risk data for informing pre-travel advice. 7 Travel Med 2015; 22:13-20.

Affiliations: Tropical Disease Unit, Division of Infectious Diseases, Department of Medicine (Boggild, Kain), University Health Network and the University of Toronto; Public Health Ontario Laboratories (Boggild), Public Health Ontario, Toronto, Ont.; Office of Border and Travel Health (Geduld), Public Health Agency of Canada, Ottawa, Ont.; JD MacLean Centre for Tropical Diseases and Division of Infectious Diseases, Department of Microbiology (Libman, Yansouni), McGill University Health Centre, Montréal, Que.; Tropical Medicine and International Health Clinic, Division of Infectious Diseases (McCarthy), Ottawa Hospital and the University of Ottawa, Ottawa, Ont.; Division of Infectious Diseases (Hajek), Vancouver General Hospital, University of British Columbia, Vancouver, BC; Infectious Diseases, Vancouver Island Health Authority, Department of Medicine (Ghesquiere), University of British Columbia, Victoria, BC; Hôpital Saint-Luc du CHUM (Vincelette), Université de Montréal, Montréal, Que.; Section of Pediatric Infectious Diseases, Departments of Pediatrics and Medicine (Kuhn), Alberta Children's Hospital and the University of Calgary, Calgary, Alta.; Center for Geographic Medicine, Department of Medicine (Freedman), University of Alabama Birmingham, Birmingham, Ala. SAR Laboratories (Kain), Sandra Rotman Centre for Global Health, Toronto, Ont.

Contributors: Andrea Boggild conceived the study, contributed to study design, data collection, analysis and interpretation, and was primarily responsible for writing the manuscript. Jennifer Geduld contributed to study conception, data interpretation, and critical appraisal and revision of the manuscript. Michael Libman, Cedric Yansouni, Anne McCarthy, Jean Vincelette, Jan Hajek, Wayne Ghesquiere, Susan Kuhn and Kevin Kain contributed to data collection and interpretation, and to critical appraisal and revision of the manuscript. David Freedman contributed to data interpretation and critical appraisal and revision of the manuscript. All of the authors approved the final version to be published and agreed to act as guarantors of the work.

Funding: CanTravNet is the Public Health Agency of Canada's corresponding network for tropical and travel medicine that has been funded through the Office of Border and Travel Health Division of the Public Health Agency of Canada. It has been created by grouping the Canadian sites of GeoSentinel: the Global Surveillance Network of the International Society of Travel Medicine, which is supported by Cooperative Agreement U50/CCU412347 from the Centers for Disease Control and Prevention. The funding source of GeoSentinel had no role in study design, data analysis, data interpretation or drafting the manuscript. The funding source of CanTravNet contributed to study design and critical appraisal of the manuscript, but did not have access to raw data.

Supplemental information: For reviewer comments and the original submission of this manuscript, please see www.cmajopen.ca/content/4/3/ E352/suppl/DC1 